\title{
QUEEN'S
UNIVERSITY
BELFAST
}

\section{Capitalizing on the State: The political economy of Real Estate Investment Trusts and the 'Resolution' of the crisis}

Waldron, R. (2018). Capitalizing on the State: The political economy of Real Estate Investment Trusts and the 'Resolution' of the crisis. Geoforum, 90, 206-218. https://doi.org/10.1016/j.geoforum.2018.02.014

\section{Published in:}

Geoforum

\section{Document Version:}

Peer reviewed version

Queen's University Belfast - Research Portal:

Link to publication record in Queen's University Belfast Research Portal

\section{Publisher rights}

Copyright 2019 Elsevier.

This manuscript is distributed under a Creative Commons Attribution-NonCommercial-NoDerivs License

(https://creativecommons.org/licenses/by-nc-nd/4.0/), which permits distribution and reproduction for non-commercial purposes, provided the author and source are cited

\section{General rights}

Copyright for the publications made accessible via the Queen's University Belfast Research Portal is retained by the author(s) and / or other copyright owners and it is a condition of accessing these publications that users recognise and abide by the legal requirements associated with these rights.

\section{Take down policy}

The Research Portal is Queen's institutional repository that provides access to Queen's research output. Every effort has been made to ensure that content in the Research Portal does not infringe any person's rights, or applicable UK laws. If you discover content in the Research Portal that you believe breaches copyright or violates any law, please contact openaccess@qub.ac.uk. 


\title{
Capitalizing on the State: The Political Economy of Real Estate Investment Trusts and the 'Resolution' of the Crisis
}

Accepted for Publication in GeoForum (Volume 90, March 2018, Pages 206-218)

https://www.sciencedirect.com/science/article/pii/S0016718518300502

\begin{abstract}
A burgeoning literature demonstrates how the inter-dependent relationship between the financial and real estate sectors has intensified boom-bust dynamics within urban property markets. Indeed, following the financial crisis of 2008 , this articulation of increased financial risk within cities has been evidenced in the avalanche of distressed property assets and debt that accompanied the collapse of property markets internationally. However, while research has focused on the causes of the crash and its economic, social and political impacts, knowledge is less developed regarding how the link between finance and the built environment is being re-established. How are the circuits of capital into distressed property markets being rebooted in post-crisis contexts and what are the implications for the existing political economy? In response, this article explores the development of the Real Estate Investment Trust (REIT) market in Ireland as part of a wider effort to deleverage the country's failed banking sector and to attract global, yield-seeking capital into the moribund property market. Despite their location at the nexus between financial and real estate markets, REITs have not figured highly in critical geographic discussion of the financialization of real estate. This article addresses this gap by contextualising the history, politics and geography of REITs and by stressing their urban dimensions, as well as demonstrating how they are capitalizing on the deleveraging of the Irish banking and development sectors in the interests of global financial investors.
\end{abstract}

Keywords: financialization; Real Estate Investment Trust; financial crisis; financial chain; Ireland; political economy

\section{Introduction}

Since 2007 global real estate and financial markets have experienced a period of profound crisis that has contributed to widespread and devastating economic, social and political impacts across Subprime America and Peripheral Europe (Crump et al., 2008, Waldron and Redmond, 2017). Harvey (2011) contends the crisis is rooted in the increasingly global nature of real estate investment and the empowerment of finance capital which has stimulated asset bubbles in the property market by switching capital from investments in the productive economy into speculative investments in the built environment. In this vein, a growing body of geographic literature has examined the role of financialization as a cause and consequence of the crash (Lee et al., 2009, French et al., 2011). Financialization describes how financial markets and actors have come to occupy an increasingly dominant position in contemporary society and economy and examines the processes and effects of the growing power of financial values and technologies on economies, corporations and households (Aalbers, 2016).

A key focus of the financialization literature is the impact of the 'wall of money' that was pumped into the global real estate market from the 1990s (Fernandez and Aalbers, 2016). At the city level, this impact is evident in the avalanche of mortgage defaults, home repossessions and distressed commercial property assets that have accompanied the breakdown in the circuits that connect global financial capital and the urban built environment. The scale of this real estate/ financial crash and the magnitude of assets involved is staggering. European banks currently hold $€ 879 \mathrm{bn}$ of non-performing loans, the majority of which are linked to speculative property assets (BTG Global Advisory, 2015). In the United States, 6.2 million homes have been foreclosed upon by banks since 2007 (Andritzky, 2014) 
and many of these have been sold to private equity investors looking to capitalise on the rebound in property values (Fields, 2014).

While an extensive literature has examined the economic, social and political impacts of the financial crisis, attention has only recently turned to how the link between finance and the built environment is being re-established post-crash (Beswick et al., 2016, Byrne, 2016b). Indeed, the question arises as to how such financial circuits are being reconfigured? By what mechanisms are distressed real estate assets being redeployed back into financial circuits? What role is the State playing to reboot the real estate-financial complex? To explore these concerns, this article focuses on the policy response to Ireland's property crash, particularly the introduction of Real Estate Investment Trusts (REITs) as part of a wider effort to deleverage the country's failed banking sector and attract capital into the moribund property market. As publically listed real estate investment companies, REITs sit at the nexus between local property markets and global financial markets, yet are remarkably under-examined in the literature (Clark and Lund, 2000, Murphy, 2008). Most REIT research comes from real estate finance or urban economics and focuses on issues like investment performance and management efficiency (Chan et al., 2003). Few consider how REITs as socio-technical innovations have been formed or how history, politics and geography have influenced their development. This is an important omission considering how REITs transform property into a tradeable income-yielding asset by connecting hyper-mobile, investment capital to immobile, local property markets (Gotham, 2006).

In response, this article firstly examines how REITs are implicated in the globalization of finance and real estate, stressing how REITs have created a new financial chain that links distressed real estate assets with global finance capital. Secondly, the article highlights the role of the State in the 'resolution' of finance-real estate crashes, not just in the reactionary absorption of toxic debts from banks and developers, but also in the active development and promotion of financial instruments, like REITs, that play a crucial role in re-establishing the conditions for growth. Finally, the article examines the investment practices of REITs and how they have capitalized on the deleveraging of the Irish banking and development sectors in the interests of investors.

Borne out of a larger project examining the re-setting of relations between the financial and development sectors and the State in post-crisis contexts, this article draws on data from 21 interviews that were conducted in 2016/ 2017 with directors and associates working in REITs, property consultancies, financial advisory firms, legal and tax consultancies, as well as public officials (Table 1). Interviewees were identified through searches of the financial press, corporate websites, annual reports and snowballing techniques. The interviews were semi-structured and open-ended and interviewees discussed issues regarding their activities to shape REIT policy and legislation, the investment strategies of Irish REITs and their market impact. These interviews are supplemented by an analysis of secondary data sources, including investment reports, articles from the financial press and REITs' investor notices to the stock market.

The article is structured as follows: section two discusses the emerging literature on practices and policies of financialization in response to the crash in order to situate the discussion of REITs as a type of 'financial chain' that connects distressed real estate assets with global financial markets. Section three discusses REITs as a network of social relations, examining the actors involved, the dimensions of their interaction and how they are implicated in the globalization of international finance and real estate. Section four contextualises the Irish property crash and discusses the role of the State in establishing the Irish REIT framework. Section five examines how REITs are capitalizing on the carcass of the Irish crash in the interests of global investors and uncovers their investment preferences and asset management strategies. Section six concludes the article. 
Table 1 - Breakdown of Interviewees

\begin{tabular}{|c|c|c|}
\hline Interviewee Number & Function & Date \\
\hline Interviewee 1 & Civil Servant - Finance & $12 / 10 / 2016$ \\
\hline Interviewee 2 & REIT CEO & $14 / 10 / 2016$ \\
\hline Interviewee 3 & Tax Advisor & $14 / 10 / 2016$ \\
\hline Interviewee 4 & REIT Management & $14 / 10 / 2016$ \\
\hline Interviewee 5 & REIT CEO & $17 / 10 / 2016$ \\
\hline Interviewee 6 & REIT Development Manager & $17 / 10 / 2016$ \\
\hline Interviewee 7 & Tax Advisor & $18 / 10 / 2016$ \\
\hline Interviewee 8 & Equity Analyst & $20 / 10 / 2016$ \\
\hline Interviewee 9 & Equity Analyst & $20 / 10 / 2016$ \\
\hline Interviewee 10 & Economist - Real Estate & $20 / 10 / 2016$ \\
\hline Interviewee 11 & Lawyer - Real Estate & $21 / 10 / 2016$ \\
\hline Interviewee 12 & Corporate Finance Advisor & $08 / 11 / 2016$ \\
\hline Interviewee 13 & Civil Servant - Finance & $08 / 11 / 2016$ \\
\hline Interviewee 14 & Civil Servant - Finance & $19 / 11 / 2016$ \\
\hline Interviewee 15 & REIT - Acquisitions Manager & $23 / 11 / 2016$ \\
\hline Interviewee 16 & Real Estate Analyst & $25 / 11 / 2016$ \\
\hline Interviewee 17 & Civil Servant - Central Bank & $21 / 12 / 2016$ \\
\hline Interviewee 18 & Civil Servant - Finance & 09/03/2017 \\
\hline Interviewee 19 & Regulator - Stock Exchange & $10 / 03 / 2017$ \\
\hline Interviewee 20 & Equities Analyst & $13 / 03 / 2017$ \\
\hline Interviewee 21 & Civil Servant - Economic Advisor & $27 / 03 / 2017$ \\
\hline
\end{tabular}

\section{Deepening Practices of Financialization in Response to Crisis}

From 2008 the circuits of capital that connect global finance with local real estate broke down with spectacular effect. This story of the crisis is familiar, where a global 'wall of money' was unleashed via financial re-regulation and innovations which facilitated the reallocation of capital globally into property investment (Guironnet and Halbert, 2014). When the bubble burst, the ensuing credit crunch halted the flow of interest bearing capital to the economy, leading to the longest post-war recession across advanced economies (Kitson et al., 2011). Without wishing to underplay these impacts, this review seeks to move beyond the consequences of the crash to focus on the actions taken to revive financial flows back into distressed real estate and facilitate deepening practices of financialization. Three relevant themes are identified which situate the discussion of the role of REITs in the 'resolution' of the Irish crash; the role of the State as a market maker, the expansion of private equity into property and the role of financial innovations in expanding the terrain for the financialized economy post-crash.

\section{Financialization and the State}

Despite conspicuous interventions to buttress financial markets from 2008, the State's role in resolving finance-led property crashes has only recently become a research focus. Two productive avenues have been forged regarding the 'roll up' of private banking liabilities through State-backed Asset Management Companies (AMCs) (Byrne, 2016a, Ashton, 2011) and the 'roll out' of public assets to private financial actors (Aalbers, 2016). Regarding the former, a key problem arising from the breakdown in financial circuits following a property crash is the uncertainty of asset valuations, which hampers credit issuance and market liquidity. Public AMCs are typically introduced to isolate problematic assets from the wider financial sector, address the uncertainty of their valuation and crystallise the losses associated with such assets through State-backed asset sales (Byrne, 2016a). 
Typically these sales occur on advantageous terms to investors, involving steep discounts on the original par value of debt and often at significant cost to taxpayers (Janoschka and Alexandri, 2017). AMCs are thus deployed as 'market makers,' tasked with generating liquidity and transactions in a collapsed market based on their ability to establish an artificial price floor and control the supply of property being redeployed to the market. The establishment of AMCs was the primary response to the crash in Europe, with $€ 264 \mathrm{bn}$ of private property debt transferred to the public bourse (Cushman \& Wakefield, 2014).

The 'roll out' element of the State's actions speaks to the related processes of privatization and financialization. Here, the State can actively intervene in markets through privatization practices to create the conditions for financialization to occur (e.g. the sale of social housing units to tenants which leads to greater levels of mortgage borrowing). In other cases, the privatization process itself can become financialized, where entire portfolios of publically owned land, housing and infrastructural assets are sold en-bloc to private equity investors, in a process termed 'financialized privatization' (Aalbers, 2016, 3). Crucially, the State intervenes to manipulate values within the market, often under conditions of economic stress or fiscal austerity, and typically enacts private sales of assets on highly advantageous terms for investors (Peck and Whiteside, 2016). Such practices are required to boost market transactions and stimulate economic growth; to attract external (scarce) capital which may be required to re-equitize a market following a crash; and augment capital circulation by freeing up "sunk" public investments and making them liquid by promoting them to private investors (Mercille and Murphy, 2015). In Germany, Wijburg and Aalbers (2017) document how 500,000 social housing units were sold to private equity investors between 1999 and 2006, while Fields (2013) notes the same trend in New York's rent stabilised market, where investors displace longterm residents in order to extract higher rents. In the land market, both Christophers (2017) and AlShehabi and Suroor (2016) examine how the State through technical valuation exercises (in the former) and outright dispossession (in the latter) diverts public lands to private financial interests. The State's urban infrastructure has also been a target, including parking meters (Ashton et al., 2014), water utilities (Bayliss, 2014) and airport facilities (Deruytter, 2015), where investors acquire and manage these assets to extract higher returns but also to leverage debt onto these utilities which can then be redirected to more profitable uses. Through such actions the State contributes to the financialization of real estate by reinforcing the extraction of value from urban space, thereby rebooting the mechanisms that led to the crisis conditions in the first place.

\section{Accumulation by Repossession}

While Harvey's (2005) conception of 'accumulation by dispossession' explains how the State responds to economic crises through the 'privatization of social assets,' scholars have recently added the notion of repossession to better capture the 'socialization of private losses' that accompanied the crash of 2008 (Whiteside, 2012). Accumulation by repossession has been a key feature of the crisis response, marked by the aggressive entry of private equity and other institutional investors into distressed property markets who often acquire devalued assets at 'fire-sale' prices (Mercille and Murphy, 2015). On the supply side, such funds are attracted by the devaluation of the targeted markets, the potential for reversionary uplift and the opportunity to utilise property assets to underpin new financial instruments (Beswick et al., 2016). On the demand side, investors have been empowered by loose monetary policies, like quantitative easing, while a low growth macro-economic environment has enhanced the attractiveness of real estate as a store of wealth (Fernandez et al., 2016).

A growing literature examines how private equity funds are acquiring vast quantities of distressed property assets from AMCs, deleveraging banks and through Real Estate Owned sales. In Europe, such funds purchased $76 \%$ of the $€ 96.7 \mathrm{bn}$ of distressed property debt brought to the market by AMCs between 2012 and 2014 (Byrne, 2016c), while American investors have deployed \$20bn in 
the acquisition of 200,000 single family homes since 2012 (Fields, 2014). Such investors typically invest in highly spatially selective ways, often targeting low-value properties in low-income neighbourhoods that have experienced elevated levels of foreclosures (Immergluck and Law, 2014b, Ellen et al., 2015). Some investors are short-term oriented, capitalizing on the speculative flipping of properties without making significant improvements, while others 'milk' the assets by minimising expenditure maintenance while profiting through the continual tenant turnover (Mallach, 2010). Others utilise longer-term 'buy-to-rent' strategies, looking to upgrade properties to justify increased rents from wealthier tenants, thereby contributing to processes of gentrification and displacement (Immergluck and Law, 2014a). Larger funds have developed a new institutional asset class in the rental sector by bundling rent receivables into securities products for sale in the secondary market; an opportunity valued at \$1.5tn (Fields, 2014). This acquisition of large portfolios of distressed assets has enabled investors acquire near-oligopolistic control over local property markets as planning over a key economic sector is removed from public control.

\section{Financial Innovation in Response to Crisis}

For Harvey (2011), financial innovation has always been crucial to capitalism's survival and particularly in response to economic crises when numerous blockage points can disrupt the liquidity necessary for capital accumulation. Some scholars have focused on the implementation of new financial innovations to open up new spaces and sectors in the built environment for the penetration of finance post-crash, while others have examined the re-regulation of finance to understand how financial actors have ensured reforms are beneficial to their interests (Christophers, 2016). Speaking to the latter, Engelen (2015) describes how Dutch financiers successfully resisted greater regulatory controls on their securitisation practices by creating new sources of legitimacy and political support based on the narrative that Dutch securitisations were fundamentally less risky than the American variant and served an important intermediary function in the economy that was in the public interest. Similarly in Ireland, vested banking interests successfully diluted new mortgage lending restrictions that were introduced to curb reckless over-lending by utilising a narrative that such restrictions were limiting access to homeownership for first-time-buyers (Gerlach, 2016).

Regarding the former, Wainwright and Manville (2017) consider the development of a new market in social housing bonds in the UK, which serve to connect housing associations with financial intermediaries. Such associations have drawn f23bn in debt from investors to plug diminishing budgets under austerity conditions, but this has also changed the associations' management of their portfolios to deliver higher investor returns through more selective allocation strategies and engaging in housing development for the private sector. Still others have examined the development of new technological platforms and data harvesting techniques that allow for the extraction of consumer information to create new avenues for treating property as a financial asset (Immergluck and Law, 2014a). Investors have increasingly harnessed hyperlocal data sources, cloud computing and mobile technologies to automate and systematize investment decisions in distressed real estate and generate efficiencies that cannot be captured through traditional 'on-the-ground' home appraisals (Robinson, 2012). New data capturing applications also enable investors to classify prospective tenants as 'good' or 'bad' rental risks, allowing them identify the most profitable tenants and blacklist less desirable households (Fields, 2014). Such datafication practices enable the quantification of investment of risks, which in itself facilitates greater scale of investment.

\section{Financial Chains: Rebooting Financial Flows into Real Estate}

What connects these research avenues is a concern with the 'transmission mechanisms' that reboot capital flows between financial markets and the built environment (Halbert and Attuyer, 2016). In a similar vein, Sokol (2017) has recently developed the concept of 'financial chains' to focus on the 
channels of value transfer and the social relations that enable the extraction of value from people and places and the production of new spaces of financial exploitation. The concept captures both the mechanisms (i.e. financial instruments, econometric models and legal forms) that transfer value across space and the networks of financial actors that shape economic geographies. Sokol (2017) uses the concept in relation to the credit-debt relationships that connect banks, states and households; however, it could equally explore the financial instruments, practices and social relations that reconnect the circuits of capital flowing through financial markets with those circulating in the built environment.

As a socio-technical innovation that channels global financial capital into real estate, transforms property into a tradeable commodity and binds a vast array of finance-real estate actors together (next section), a REIT can be considered a specific form of financial chain, and one that has been central to the recovery in global property markets. Investment in the global REIT sector surged from 2011 (EY, 2016) and in the US they have been credited with re-equitizing the real estate sector and generating exceptional investor returns (The Economist, 2016). However, few scholars have undertaken fine-grained analyses of how REITs, working as a channel of value extraction and as a social relation, transform the fixed, idiosyncratic nature of property into a standardised, global and easily transferable financial asset (Gotham, 2006, Daniels, 2015). The analysis presented below addresses this task by exploring the inner-workings of the REIT structure, before discussing how REITs are reconnecting financial flows into distressed real estate in the interests of global financial capital.

\section{Real Estate Investment Trusts}

A Real Estate Investment Trust is a publicly listed company whose main activity is the ownership and management of income-producing real estate and allows investors to hold property through shares rather than direct investments (Chan et al., 2003). REITs are typically exempt from tax on rental income and capital gains subject to certain restrictions on ownership, borrowing and distributions of earnings (Brueggeman and Fisher, 2008). While the REIT concept originates in the business trusts of mid-19 $9^{\text {th }}$ century America, it was not until 1960 that the US Congress formally established their legislative basis (The Economist, 2016). Difficult economic conditions stymied their growth in the 1970s, but following significant tax breaks and regulatory restructuring in the 1980s the US REIT market expanded dramatically from \$1.5bn (1970) to \$11bn (1989) (Chan et al., 2003). However, REITs remained a largely US-centric investment form, with only the Netherlands (1969) and Australia (1971) being early adopters of the model (Mazurczak, 2011). It was only following the Asian Financial Crisis of 1997 that a marked expansion in REIT regimes was noted in Japan (2000), South Korea (2001), Singapore (2002) and Hong Kong (2003) (Stevenson, 2013). European countries were late adopters of the REIT model, with France developing its market in 2003, before being followed by Germany, Italy and the UK in 2007. By 2006 the capitalisation of the global REIT market was $\$ 850 \mathrm{bn}$, and while this was impacted by the financial crisis, the market rebounded sharply to a capitalisation of $\$ 1.7$ trillion by 2016 (EY, 2016). Indeed, the large volumes of distressed real estate assets created by the crash was a primary impetus for the expansion of REIT systems in Europe, including in Ireland (2013) and Spain (2014) (Interviewees 2, 3, 18).

Understanding the REITs' organizational structure is key to understanding how they transform spatially-fixed property into a tradeable, income-yielding financial asset. While this structure depends on national regulatory frameworks (KPMG, 2015), Figure 1 outlines an example for the Irish context. The first issue to highlight is the division of responsibilities between the REIT Company and the Investment Manager, which are two distinct legal entities. The former is the legal owner of a portfolio of properties and is governed by a Chairman and Board who are responsible for setting the company's strategic objectives. The latter is responsible for the day-to-day management of the company's assets, implementing the REIT's investment policy and financing strategy and makes annual distributions to investors in exchange for advisory fees. Some jurisdictions enforce a separation between the 'owners' 
and 'managers' of the trust's property assets, primarily as a safeguard for shareholders' interests (Daniels, 2015). In practice, however, these entities are closely related, often with the investment manager being owned by the REIT or the REIT's board being staffed by employees of the investment manager (McCabe, 2014).

Figure 1 - Organizational Structure for Irish REIT

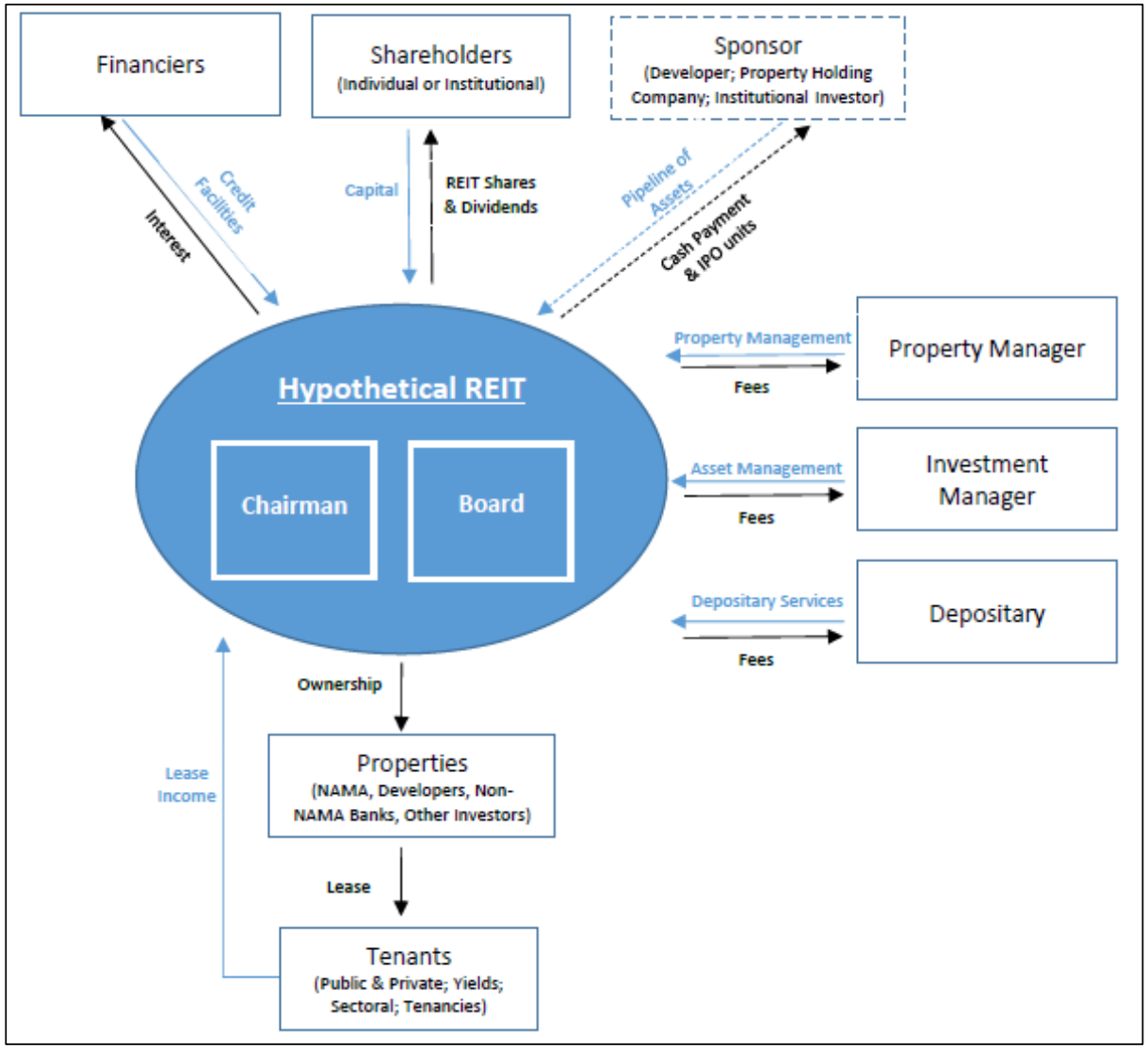

Adapted from Daniels $(2015,18)$

The Investment Manager is the interface between the financial markets and local property assets and works to transform property into a liquid commodity. The manager identifies and acquires investment assets and is responsible for managing the REITs portfolio to generate sufficient rental income to distribute to shareholders (Interviewees 2, 5, 12, 14, 15, 16). REITs' assets may be acquired in the open market or they may come from a 'Sponsor,' which is generally a private property company that wishes to monetise and convert the value of their properties into shares by selling their portfolio to a REIT. Alternatively, a REIT could be established as a 'cashbox' entity, where the REIT raises capital via an Initial Public Offering (IPO) from speculative investors without owning any assets upfront that could be used as collateral to safeguard investors' interests (Pirolo and Neumann, 2015). Effectively, investors act as pure venture capital funds, advancing capital on little more than the reputations of the REIT syndicators and a prospectus of potential acquisitions. As investors are often geographically disconnected from their investment locales and the local knowledge necessary to assess risk, their trust in the credibility of the REIT's investment managers is critical for the generation of liquidity (Interviewees 2, 12, 20).

In accessing investment capital, the REIT manager's key task is to seek out 'cornerstone investors,' who can take a large share in an initial fundraising round and entice smaller investors to follow them by virtue of their size and reputation (Interviewees 2, 3, 4, 5, 16, 19). These cornerstones are usually recognisable names on Wall Street or the City of London and include large private equity 
funds, hedge funds or other institutional investors. Typically, the assistance of bridging actors is required and these are specialist legal firms, investment banks and corporate brokers who act as intermediaries between the REIT's management and the capital markets (Interviewees 8, 9, 12, 20). The analysts that cover REITs for corporate brokers are the key conduits through which the REIT accesses shareholder capital. These analysts construct bespoke econometric models for each REIT and project levels of supply and demand for commercial floor space, the expected timing of development pipelines, how future investment yields and rents will fluctuate and determine how these might affect returns (Interviewees $8,16,20$ ). They calculate a projected net asset value figure, which is the metric that informs their buy, sell or hold recommendations that translate the REIT's property investments into a standardised, legible format for investors (Crosby and Henneberry, 2015).

As investments, REITs sit between high-growth stocks and bonds as they provide both continual income streams in dividend payments from rents and long-term capital appreciation through stock price increases. There are typically three types of investor in REITs (Interviewee 12). The first are 'opportunistic investors' who are generally short-term, high-risk private equity funds seeking to capitalise on the devaluation of assets in the aftermath of a market crash when few other investors are willing to. The second group are 'income investors' who are large public equity funds who are concerned with securing long-term, steadily appreciating income streams to fund their pension, endowment or insurance commitments. These represent the "longer, stickier money...in the trilliondollar range" who can access capital at very low interest rates but who may be precluded from investing in high-risk markets due to prudential requirements (Interviewee 2). The third category are 'Specialist REIT Investors' who are investment managers that only invest in listed real estate stocks and typically buy out the first category of 'opportunistic investors.'

The type of investor capital can have important consequences for the REIT's investment policy and influence the geographic, temporal and sectoral flow of capital into the built environment (Interviewee 12). As income-driven investors are more concerned with dividend-producing investments, they prefer REITs to acquire high quality properties let with long leases to high credit tenants in core locations. Income-driven investors may also focus more on a REIT's development pipeline where redevelopment and active asset management can deliver greater income generating growth. Specialist investors tend to focus on efficiencies in management costs and pay particular attention to borrowing levels and leverage because these costs are paid from the property rental flows that also pay investors' dividends. Hence, specialist investors prefer conservative levels of gearing and favour high quality properties that require little to no improvement. More opportunistic investors will encourage REIT management to seek out more speculative portfolios of assets to capitalise on the uplift in values in a market recovery. Opportunistic investors may also be more agnostic about REITs taking on greater levels of debt, as they seek to utilise higher levels of financial leverage to take the arbitrage between the property yield and the cost of debt.

From a government perspective, REITs are attractive as a new source of development capital for the construction sector and as a lower entry cost to the property market for small investors (Interviewees 14, 18). It is argued REITs encourage greater professionalization in the rental market by attracting large property investors and managers, thereby improving housing supply conditions (Interviewee 13). However, the most important aspect for government is their ability to draw new sources of capital into the property market and promote transactions, particularly where investors are risk averse following a market crash (Interviewees 14, 18, 21). As demonstrated above, where the domestic investor base has been wiped out and economic conditions are volatile, REITs backed by international capital have often been used to 're-equitize' the property sector. Or from a political economy perspective, REITs are a mechanism for pooling investor risk to establish new circuits of financial capital back into distressed real estate markets and recreate the appropriate conditions for the renewed accumulation of capital (Harvey, 2005). 


\section{The Development of Ireland's REIT Structure}

To contextualise the development of the Irish REIT model, it is necessary to briefly set the scene of the Irish property bubble and bust. The political and economic dynamics which drove the crash are well established, and include the internationalisation of the Irish banking sector (Hendrikse, 2013), a highly liberalised credit market for real estate (Kelly, 2010) and pro-cyclical fiscal policies in support of the construction sector (Williams and Nedovic-Budic, 2016). These forces fuelled a dramatic expansion in bank lending into property as the construction sector became an increasingly dominant sector in the Irish economy (Ó'Riain, 2013). However, this reliance was to have profound economic and social implications following the collapse of Lehman Brothers bank in September 2008. This event precipitated an international credit crunch which saw the overleveraged Irish banks locked out from international financial sources at the same time as domestic investors withdrew from the property market (Lane, 2011). Confidence in the Irish banking system and property market evaporated as the banks' share values collapsed by $90 \%$ and the value of residential and commercial property fell by over 50\% (Waldron and Redmond, 2016). The circuit of capital connecting the Irish financial system with investments in the built environment seized and was unable to be rebooted by the private market given the uncertainty regarding asset valuations.

In response, the State introduced an exceptionally broad public guarantee of the banks' private liabilities ( $€ 485 \mathrm{bn}$ ), while also recapitalising their decimated balance sheets with taxpayer funds (€64bn). In the property market, the Government established a 'bad bank,' the National Assets Management Agency (NAMA), to purchase distressed property loans from the banks in return for public bonds with the aim of removing the banks' riskiest loan classes (Cardiff, 2016). NAMA became a repository for the failed development-finance sector as 11,000 loans secured against 60,000 properties with an initial loan value of $€ 74 \mathrm{bn}$ were transferred to NAMA at a cost of $€ 32 \mathrm{bn}$ (Williams, 2014). NAMA actually paid a $15 \%$ premium on the market value of the distressed assets to represent long-term economic value, demonstrating the State's commitment to enhancing property values through the creation of an artificial floor on prices.

While the NAMA Act (2009) stipulates the agency must divest itself of its assets by 2020, in reality NAMA has self-imposed a more stringent timeframe for its portfolio sales. In 2010 NAMA committed itself to repaying $25 \%$ of its senior bonds ( $€ 7.5 \mathrm{bn}$ ) by December 2013, while in 2014 the agency announced it would be wound up two years earlier than its statutory deadline, thereby committing itself to selling a large volume of devalued real estate within a very short timeframe. Consequently, a coterie of international financial funds has aggressively entered the Irish market, capturing vast quantities of devalued property debt and assets on highly favourable terms. For example, NAMA's 'Project Arrow' portfolio consisted of $€ 6.25 \mathrm{bn}$ in non-performing debt secured against 1,906 properties and was sold to Cerberus Global Investors for $€ 800 \mathrm{~m}$; a write-down of $88 \%$ (O'Halloran, 2015). Crucially, the shortfall between the par value of these debts and that realised by NAMA sales has been foisted onto the State through the bank recapitalisation programme in what amounts to taxpayer subsidised fire-sales of nationalised property assets back to the private market.

Recognising the lucrative opportunity created by the devaluation in Irish property and the concentration of assets in NAMA, a consortium of highly-influential property sector stakeholders formed a lobbying group in 2011 known as the 'Irish REITs Forum' to promote an Irish system of Real Estate Investment Trusts (Interviewees 2, 4, 7, 11, 12, 16). Comprised of eleven institutions from Ireland's real estate advisory, tax consulting, corporate finance, wealth management and legal sectors, the Forum gathered a fighting fund of resources and specialist expertise to lobby the Department of Finance, the Revenue Commissioners, the Central Bank and NAMA (O'Neill, 2013). Their efforts entailed compiling data on the operation of REIT regimes internationally, undertaking formal presentations to outline the investment rationale and generating political capital for the proposal (Interviewees 4, 7, 12, 16). Sometimes the Forum sought to influence policy via direct means, such as through representations to formal policy making committees (Department of Finance, 2012). However, informal strategies of influence were also vital, particularly establishing interpersonal 
relationships with key political advisors and policymakers who were framing the Government's crisis response. For example, one senior member of NAMA's executive team had formerly lobbied the Irish Government to introduce a REIT-like structure in the late-1980s and was a key contact in generating political support behind closed doors (Interviewee 4). In another case, the Secretary General of the Department of Finance, who had previously worked as a REIT lawyer in New York, was identified as someone who was predisposed to the Forum's aims (O'Neill, 2013).

On the back of these interventions, the Irish Government established a REIT framework in the Finance Act 2013. A number of factors influenced the Government's decision, not least their concern that Ireland's tax treatment of property investment was dissuading foreign investors and because of a lack of diversification in the sources of development capital (Interviewees 13, 14, 18). Most importantly, the Minister for Finance (2012) outlined that REITs would "...assist NAMA in deleveraging its portfolio and allow it to bring more sustainable activity to the commercial and residential property markets." Significant tax advantages were written into the REIT legislation, allowing international investors minimise their tax exposure. A REIT is exempt from corporate tax provided it distributes $85 \%$ of its annual earnings to shareholders, derives $75 \%$ of its profits from rental property and maintains a loan-to-value ratio below $50 \%$. Instead, income tax is applied to domestic investors on their dividend payments and capital gains tax on the sale of their shareholdings (Interviewees 3, 7, 11). Foreign investors are subject to withholding tax (20\%) on their dividend income, but certain investors can be exempt from this withholding tax subject to the nature of the tax treaties signed by their resident jurisdictions with Ireland (ibid). This taxation structure has been vigorously criticised by some opposition parliamentarians, questioning whether these exemptions breach the European Commission's rules on state aid (Quinlan, 2016).

\section{Capitalizing on the Crash: Irish REITs as a Channel of Value Transfer}

The enactment of the Irish REIT system in 2013 coincided with a period when international financial funds were seeking to speculatively access the Irish property market and which Government policy was complicit in facilitating in a number of ways. Firstly, by establishing NAMA in 2009 the Irish State began offloading portfolios of distressed assets to investors much earlier than other European countries. Secondly, unlike Spain's 'bad bank' SAREB, NAMA absorbed both performing and nonperforming loans, meaning that the quality of acquisitions was considerably more profitable for investors (Byrne, 2015). Thirdly, NAMA is a significantly smaller organisational entity, comprised of just 800 debtors when compared to SAREB's 19,000, meaning the agency could work through its portfolios more swiftly (Flanagan, 2016). Fourthly, US investors were particularly attracted to Ireland as an English-speaking country with a common law legal system, strong private property rights and a pro-business political environment (Interviewees 3, 11, 14, 18). Finally, the scale of deleveraging in the banking sector meant Ireland became the most active commercial real estate market in Europe, as sales of commercial real estate loans reached $€ 26 \mathrm{bn}$ in 2015 and Irish property outperformed a range of comparator financial assets (Figure 2). 


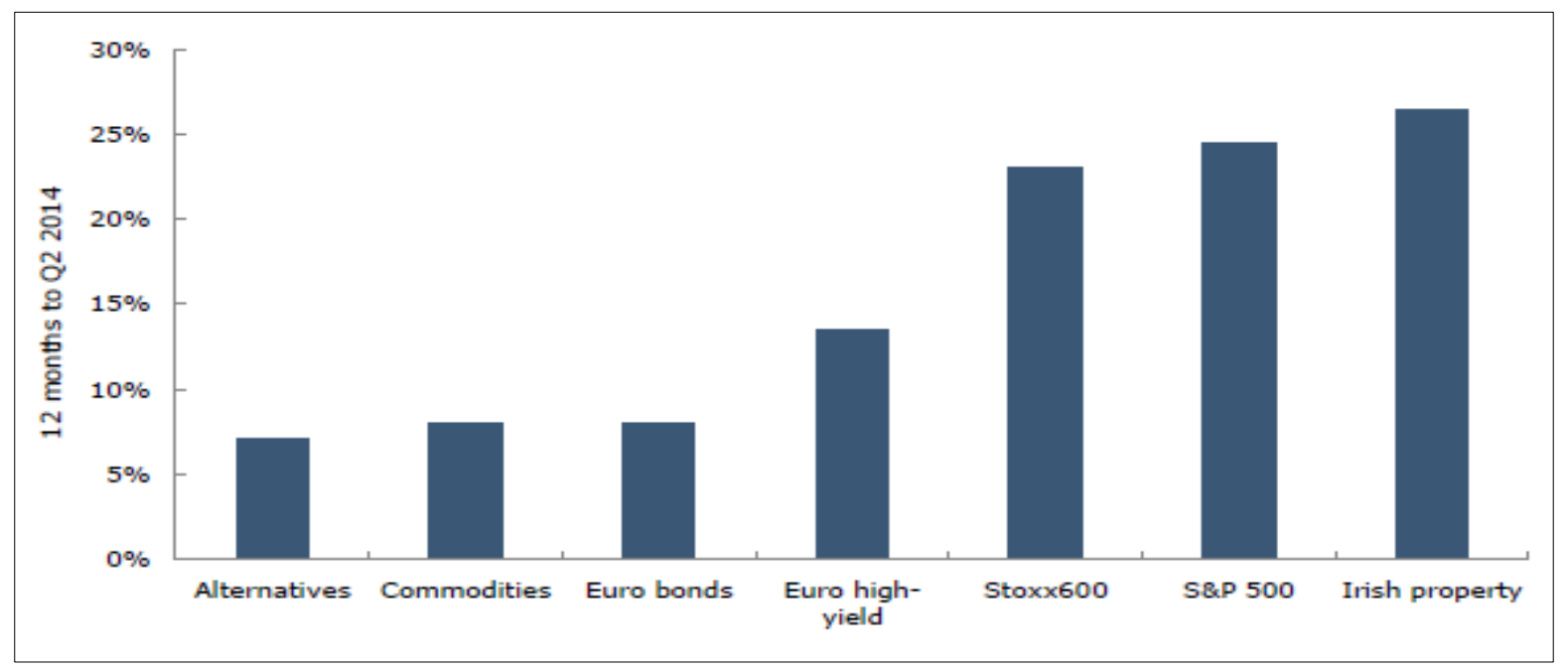

(Goodbody Stockbrokers, 2014, 9)

While many investors capitalised on the carcass of the Irish crash through direct property acquisitions, others played the market turnaround by investing in the three Irish REITs that were established from 2013 (Table 2). The first of these was Green REIT, a cashbox investment vehicle formed in July 2013 by Stephen Vernon, one of the few domestic investors to emerge unscathed from the debt-fuelled speculation of the 'Celtic Tiger' years. By trading on this investment reputation, their relationships with NAMA and their local market knowledge, Green raised $€ 685 \mathrm{~m}$ in shareholder capital, reflecting the insatiable demand among global investors for Irish property. Hibernia REIT was established in December 2013 by Bill Nowlan, the founder of the Irish REIT Forum. Again, without owning any underlying assets to act as collateral for shareholders, Hibernia raised $€ 665 \mathrm{~m}$ to invest primarily in Dublin office developments. In April 2014, IRES REIT was established as a subsidiary of the investment group CAPREIT which owns 48,000 apartments across Canada. Identifying the potential rebound in residential property values and rents following the crash, IRES raised $€ 415 \mathrm{~m}$ in shareholder capital which it has deployed in the acquisition of multi-tenanted apartment blocks in Dublin, leading CEO David Ehrlich to proclaim that Ireland is the most profitable market he has ever encountered (Reddan, 2016).

Table 2 - Overview of the Irish REIT sector

\begin{tabular}{|l|ccc|}
\hline & Green REIT & Hibernia REIT & IRES REIT \\
\hline Listing Date & $18 / 07 / 2013$ & $11 / 12 / 2013$ & $16 / 04 / 2014$ \\
Shares in Issue (Dec 2015) & $680,864,987$ & $681,251,285$ & $417,000,000$ \\
Market Capitalisation (Dec 2015) & $€ 1,084,617,924$ & $€ 959,201,809$ & $€ 487,890,000$ \\
Target LTV & $35 \%$ & $35 \%$ & $45 \%$ \\
Target Return & $10 \%-15 \%$ & $10 \%-15 \%$ & $10 \%-15 \%$ \\
Debt Facilities & Barclay's Bank (€290m) & Bank of Ireland (€190m) & Barclays Bank (€140m) \\
& Bank of Ireland (€150m) & Ulster Bank (€70m) Bank (€162.5m) & IRES Fund Management \\
Investment Manager & Green Property REIT Ventures & Nowlan Property REIT & Residential \\
Primary Sectoral Focus & Commercial & Management & Commercial \\
\hline
\end{tabular}

(Source) Annual Reports and Stock Market Notices 
A key selling point of the REIT Forum in their lobbying activities was that REITs would enable "...Joe Public to invest in professionally managed Irish property ... just as if they were big guys or pension funds" (Nowlan, 2013). However, this is a fiction (Table 3). REITs' shareholders are not 'mom and pop' investors but global hedge funds and institutional investors who are deploying tens of millions of euro to capture devalued assets and exploit rent gaps through the REITs (Interviewees 4,5, 15,20 ). For example, Franklin Templeton, the California-based investment fund which earned $€ 5.6 \mathrm{bn}$ by speculating in Irish government debt in 2011, established considerable positions in both Green and IRES. Paulson and Co, the $\$ 19 \mathrm{bn}$ hedge fund which specialises in 'event driven arbitrage strategies,' built up a $12 \%$ share in Green REIT. The $\$ 25 \mathrm{bn}$ fund controlled by George Soros, who famously shorted the British pound in 1992, was a major cornerstone investor in Hibernia. As investment in the broader Irish property market accelerated from 2013, so did the value of the shareholdings of these early investors. By December 2015 Green and Hibernia's share values had risen by $60 \%$ and $43 \%$ respectively, meaning early investors could profit from remarkable capital gains by unwinding their positions through secondary sales on the stock exchange. In one instance, Paulson and Co. netted a handsome profit of $€ 23 \mathrm{~m}$ by reducing their holding in Green from $11.2 \%$ to just $8.7 \%$ in October 2015 (McCabe, 2015).

Table 3 - REIT Investors by Percentage of Issued Share Capital, 2015

\begin{tabular}{|c|c|c|c|c|c|}
\hline \multicolumn{2}{|l|}{ Green REIT } & \multicolumn{2}{|l|}{ Hibernia REIT } & \multicolumn{2}{|l|}{ IRES REIT } \\
\hline Shareholder & Oct-15 & Shareholder & Mar-15 & Shareholder & Dec-15 \\
\hline Franklin Templeton & $11.85 \%$ & Soros Fund Management LLC & $7.78 \%$ & CAPREIT Limited Partnership & $15.70 \%$ \\
\hline Paulson \& Co Inc & $11.18 \%$ & Mainstay Marketfield Fund & $6.91 \%$ & Franklin Templeton & $13.10 \%$ \\
\hline Threadneedle Asset Management & $7.07 \%$ & Putnam Investments LLC & $5.73 \%$ & Setanta Asset Management & $11.91 \%$ \\
\hline MainStay Marketfield & $5.99 \%$ & TIAA-CREF & $5.43 \%$ & Irish Life Investment Managers & $5.96 \%$ \\
\hline LVS II/ PIMCO Bravo Fund II L.P & $4.64 \%$ & INVESCO & $4.94 \%$ & INVESCO & $4.17 \%$ \\
\hline Blackrock Inc & $4.45 \%$ & Wellington Management Co. & $4.09 \%$ & Schroder plc & $4.04 \%$ \\
\hline Zurich Life Assurance PLC & $4.41 \%$ & Goodbody Stockbrokers & $3.61 \%$ & APG Asset Management N.V & $3.60 \%$ \\
\hline Investec Asset Management & $3.97 \%$ & Zurich Life Assurance plc & $3.37 \%$ & GLG Partners LP & $3.17 \%$ \\
\hline INVESCO & $3.04 \%$ & Oppenheimer Funds, Inc & $3.16 \%$ & Alken Fund SICAV & $3.09 \%$ \\
\hline Morgan Stanley IM & Less than $3 \%$ & Morgan Stanley IM & $3.02 \%$ & Prudential Financial Inc & $3 \%$ \\
\hline Total & $56.60 \%$ & Total & $48.04 \%$ & Total & $67.74 \%$ \\
\hline
\end{tabular}

(Source) Annual Reports and Stock Market Notices

Through 2016 these early opportunistic investors have been increasingly replaced by shareholders with longer-term investment strategies (Interviewees 4, 5, 6). Paulson and Co. reduced their holdings in Green below $2 \%$ by early 2016, while Fir Tree Partners and Starwood Real Estate Securities, two American hedge funds, reduced their 22\% stake in IRES to zero (Brennan, 2017). In their stead have come pension and life assurance funds, such as Zurich Life Assurance and TIAA-CREF, which are more driven by a need to match long-term liabilities with steadily appreciating rental dividends. This change is occurring for a number of reasons. Firstly, opportunistic investors recognised that the 3-year window in which easy gains could be made from the uplift in property values had closed by 2015 (Interviewees 4, 12, 16). Yields on prime Irish office assets halved between 2011 and 2016, meaning that investors would have to support costly (and risky) asset improvements if they wanted to realise further profits. Secondly, NAMA has offloaded the most lucrative portfolios and the agency admits it is "getting tougher and tougher" to generate investor interest in the remaining assets (Flanagan, 2016). Thirdly, more profitable opportunities exist in other Eurozone countries like Spain, where reprivatisation sales are also underway (Janoschka and Alexandri, 2017). Fourthly, as Ireland's 
economic outlook improved, institutional investors were no longer precluded from investing in the country due to prudential considerations (Interviewee 5). Finally, as Irish rents have doubled since the crash, investors' dividends have risen sharply. Green's dividend increased by over $400 \%$ (€6.1m $€ 31.4 \mathrm{~m}$ ) between 2014 and 2016, while IRES' growth was even more dramatic (€1.8m - €20.4m). In capturing such revenue streams global investors syphon off the value created in the domestic recovery, acquiring buildings as financial commodities rather than for their potential within the urban fabric (van Loon and Aalbers, 2017).

\section{REITs' Acquisition and Disposal Strategies}

From 2014 the REITs deployed an astonishing $€ 2.23 \mathrm{bn}$ in shareholder capital and debt to acquire 4.7 million square feet of commercial floor space, 286 acres of development land and 2,448 residential units (Table 4). While some assets have been flipped for a profit, the REITs are riding the uplift in the wider market as the value of their holdings have appreciated substantially. Green's portfolio of office, industrial and retail buildings was acquired for some $€ 959 \mathrm{~m}$, yet the valuation of their current portfolio stands at $€ 1.24 \mathrm{bn}$. Hibernia spent some $€ 750 \mathrm{~m}$ acquiring office and residential buildings, yet the value of these acquisitions has appreciated by $24 \%$ to $€ 928 \mathrm{~m}$. IRES' portfolio of 2,378 apartments, making it the largest private landlord in the State, was acquired for $€ 596 \mathrm{~m}$, yet the value of this portfolio has risen by $15 \%$ to $€ 685 \mathrm{~m}$. Rising valuations not only generate increased investor interest in the REITs, but also provide more valuable collateral upon which the REITs can draw down debt for further investment. Indeed, the three REITs have signed revolving credit facilities totalling $€ 1.09 \mathrm{bn}$ with a number of banks (Table 1), providing them with an enormous overdraft to fund acquisitions and flexibility regarding the number and timing of drawdowns and repayments.

Table 4 - Acquisitions of the Irish REIT sector

\begin{tabular}{|c|c|c|c|}
\hline & Green REIT & Hibernia REIT & IRES REIT \\
\hline Total Acquisitions Since Listing & 27 assets & 35 assets & 19 assets \\
\hline Total Portfolio (2016) & 21 assets & 25 assets & 19 assets \\
\hline Total Invested (2016) & $€ 959.3 \mathrm{~m}$ & $€ 750$ & $€ 529 \mathrm{~m}$ \\
\hline Portfolio Valuation (2016) & $€ 1.24 \mathrm{bn}$ (21 assets) & $€ 928 \mathrm{~m}$ (25 assets) & $€ 662.7 \mathrm{~m}$ ( 25 assets) \\
\hline Net Profit for Year (2016) & $€ 145.5 \mathrm{~m}$ & $€ 136.8 \mathrm{~m}$ & $€ 24.7 \mathrm{~m}$ \\
\hline Net Profit Since Listing & $€ 345.5 \mathrm{~m}$ & $€ 227.3 \mathrm{~m}$ & $€ 39.5 \mathrm{~m}$ \\
\hline \multicolumn{4}{|l|}{ Portfolio Comprised of: } \\
\hline Commercial Floor space (sq ft) & $3,259,174$ & $1,127,784$ & 330,538 \\
\hline Development Land & 237 acres & 46 acres & 3 acres \\
\hline Residential Units & - & 384 apartments & 2,378 apartments \\
\hline \multicolumn{4}{|l|}{ Value Portfolio by Sector (€m) } \\
\hline Office & $€ 974.7$ & $€ 803$ & - \\
\hline Retail & $€ 181.5$ & - & - \\
\hline Residential & - & $€ 113$ & $€ 662.7$ \\
\hline Industrial & $€ 23.6$ & $€ 12$ & - \\
\hline Other & $€ 60.9$ & - & - \\
\hline Total Portfolio & $€ 1,240.7$ & $€ 928$ & $€ 662.7$ \\
\hline \multicolumn{4}{|c|}{ Vendor (\% of acquisitions by value) } \\
\hline Deleveraging Bank/ Developer & $65 \%$ & $40 \%$ & $8 \%$ \\
\hline NAMA & $32 \%$ & $8 \%$ & $64 \%$ \\
\hline Private Equity & - & $36 \%$ & $21 \%$ \\
\hline Unknown & $3 \%$ & $16 \%$ & $6 \%$ \\
\hline Total & $100 \%$ & $100 \%$ & $100 \%$ \\
\hline
\end{tabular}

(Source) Annual Reports and Stock Market Notices 
Spatially, the REITs' investments are concentrated in a number of core and suburban locations (Figure 3). The Dublin Docklands has been a key focus because it contains the City's most valuable development land and the greatest concentration of NAMA's Irish assets (Byrne, 2016b). Hibernia has been particularly active here, acquiring control over an entire city block that is strategically located between the Irish Financial Services Centre and Dublin's emerging technology hub, the 'Silicon Docks.' Hibernia is redeveloping and rebranding this site as a new city quarter to cater to the emerging digital and fin-tech sectors. The REITs are also investing heavily in new commercial growth poles to the south and south-west of the City, drawing both employment and population from the city core and contributing to a more multi-polar and fragmented city region. Elsewhere, IRES have acquired large apartment developments in a number of rapidly gentrifying, working-class neighbourhoods to the west of the city. These investments are targeted toward higher and middle-income tenants, thereby reducing the availability of affordable housing for lower-income households. For example, in December 2016 the average monthly rent for an apartment in the Inchicore neighbourhood was $€ 1,280$ (PRTB, 2016), yet IRES units in the same area are advertised for $€ 1,675^{1}$. Such rents are contributing to displacement pressures and economic evictions in the residential market, pushing lower-income households further out of the city in search of cheaper housing.

\section{Figure 3-Spatial selectivity of REIT acquisitions across Dublin City}

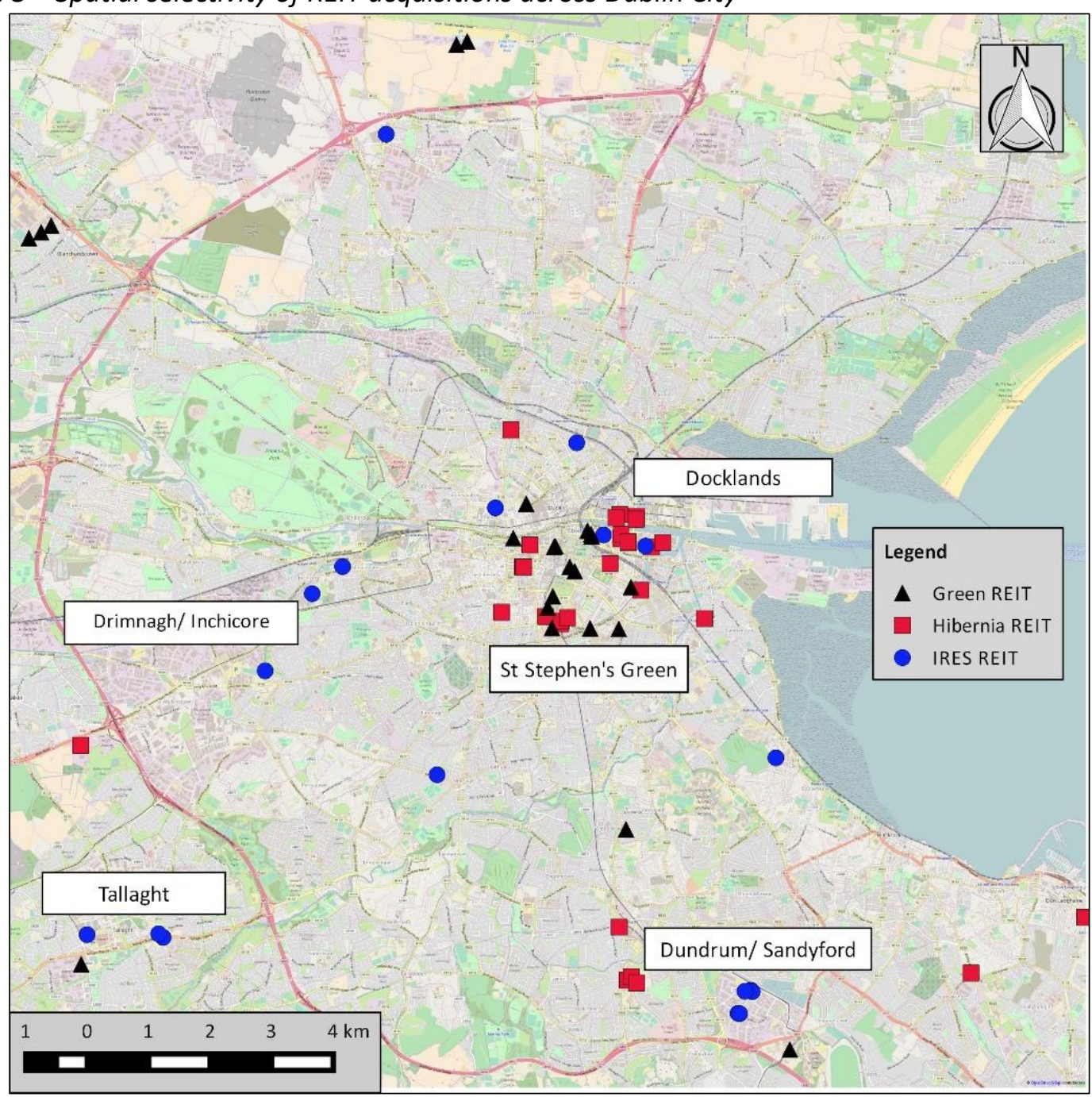

${ }^{1}$ Figure sourced from a listing on the Daft.ie property listing website, accessed on 08/05/2017 
The REITs' acquisitions come from NAMA, deleveraging banks and developers and typically occur on highly advantageous terms. For example, in September 2013 CAPREIT acquired 338 apartments in a portfolio sale from Bank of Scotland (Ireland) for $€ 42.8 \mathrm{~m}$. These assets were subsequently transferred to IRES and just two years later were valued at $€ 79.6 \mathrm{~m}$, representing a remarkable appreciation of $86 \%$. Data on NAMA sales is more difficult to source as the original par values of the debts attached to NAMA assets have never been revealed. However, the case of Central Park in Sandyford provides an indicative example. This $691,000 \mathrm{sq}$ foot office development was constructed from 1999 by Treasury Holdings, one of Ireland's largest developers, for a reported end value of IRf500m ( $€ 635 \mathrm{~m}$ ) (McDonald and Sheridan, 2008). When Treasury was liquidated owing $€ 1.7 \mathrm{bn}$ to NAMA, Central Park was sold to a consortium of Green REIT, PIMCO and Kennedy Wilson for just $€ 310 \mathrm{~m}$, with Green's share equating to $€ 114 \mathrm{~m}^{2}$. While the true cost to taxpayers may never be revealed, it is likely to be significant considering Green's valuation of its suburban office portfolio increased by $51 \%$ by 2016 . The REITs have also been an exit source for private equity investors seeking to exit the Irish market. For example, in September 2013 NAMA sold New Century House, an 86,000 $\mathrm{sq} \mathrm{ft}$ office building in the Docklands, to a private investment company called CMP Investment Partners for $€ 28 \mathrm{~m}$. This building was sold to Hibernia just 6 months later for $€ 47 \mathrm{~m}$, representing an astonishing uplift of $67 \%$. Such transactions not only question whether NAMA is achieving the best returns for taxpayers, but fundamentally highlight the agency's complicity in creating a more direct circuit between global finance and urban real estate.

\section{Rental Income}

Within the REITs' organisational framework a tension is created by the fact that the future liabilities of investors are reliant on the present rents paid by the REITs' tenants. Indeed, the doubleedged sword of exceptional shareholder returns is the rapid increases in residential and commercial rents paid by tenants as the REITs' management seek to extract the maximum return from their portfolios. The REITs have capitalized on a remarkable turnaround in the Dublin commercial real estate sector, where the vacancy rate has fallen from $23 \%$ to $6 \%$ between 2012 and 2016 as occupier demand has been driven by macro-economic growth, continued strong foreign direct investment and a substantial expansion in Ireland's fin-tech, ICT and financial services sectors (Quadrant Real Estate, 2016). In combination with a virtual absence of new commercial construction between 2010 and 2013, it is no surprise that rental levels for prime office space have more than doubled since 2012, from $€ 300 \mathrm{~m}^{2}$ to $€ 673 \mathrm{~m}^{2}$ (MacLaran, 2014).

The REITs are clearly capitalizing on such growth, channelling the exceptional rents being delivered back to their investors (Table 5). At a portfolio level Green's rent roll has expanded by $60 \%$, while Hibernia's growth rate was even more dramatic at $75 \%$. While such growth has been driven by acquisitions, as an expanding portfolio will clearly produce more income, it is also apparent they are driving up rents at the individual property level through reversionary lease agreements. In their acquisitions the REITs often targeted buildings that were under-tenanted or where leases were about to expire, meaning there was significant potential for rent increases at the next lease event (Interviewees 16, 20). Figure 4 displays Hibernia's projected rents at a selection of its city centre assets where leases are expiring between 2017 and 2019. Hibernia's management are seeking to lock-in tenants into substantially larger rental commitments as they plan to drive up rents from anywhere between $30 \%$ and $69 \%$. Only large multinational companies can actually afford the rental levels sought by the REITs, which derive around $65 \%$ of their income from large firms in the finance and technology sectors. Furthermore, the rapid acceleration in rents is pushing smaller, commercial entities out of the central business district to cheaper, peripheral locations (Comiskey, 2017). Such rent increases threaten Ireland's broader economic competitiveness, as commercial rents are the $6^{\text {th }}$ highest in the Eurozone (National Competitiveness Council, 2016).

\footnotetext{
2 In November 2015, Green REIT purchased PIMCO's share in Central Park for €155m, representing a 35\% increase in value at that time.
} 
Table 5 - Passing Rent by Real Estate Sector and Year (€m)

\begin{tabular}{|l|cccc|ccc|ccc|}
\hline \multirow{2}{*}{ Real Estate Sector } & \multicolumn{4}{|c|}{ Green REIT } & \multicolumn{3}{c|}{ Hibernia REIT } & \multicolumn{3}{c|}{ IRES REIT } \\
& $\mathbf{2 0 1 4}$ & $\mathbf{2 0 1 5}$ & $\mathbf{2 0 1 6}$ & \% increase & $\mathbf{2 0 1 5}$ & $\mathbf{2 0 1 6}$ & \% increase & $\mathbf{2 0 1 5}$ & $\mathbf{2 0 1 6}$ & \% increase \\
\hline Office & $€ 20.60$ & $€ 38.20$ & $€ 33.10$ & $61 \%$ & $€ 15.90$ & $€ 24.10$ & $52 \%$ & - & - & - \\
Industrial & $€ 0.80$ & $€ 0.80$ & $€ 1.30$ & $63 \%$ & $€ 0.40$ & $€ 0.50$ & $25 \%$ & - & - & - \\
Residential & - & - & - & - & $€ 0.20$ & $€ 5.40$ & $2,600 \%$ & $€ 28.20$ & $€ 42.35$ & $50 \%$ \\
Retail & $€ 6.00$ & $€ 12.00$ & $€ 10.50$ & $\mathbf{7 5 \%}$ & - & - & - & - & - & - \\
Other & $€ 1.20$ & $€ 1.40$ & $€ 1.00$ & $-17 \%$ & $€ 0.50$ & - & $-100 \%$ & - & - & - \\
Total & $€ \mathbf{2 8 . 6 0}$ & $€ \mathbf{5 2 . 4 0}$ & $€ \mathbf{4 5 . 9 0}$ & $\mathbf{6 0 \%}$ & $€ 17.10$ & $€ \mathbf{3 0 . 0 0}$ & $\mathbf{7 5 \%}$ & $€ \mathbf{2 8 . 2 0}$ & $€ \mathbf{4 2 . 3 5}$ & $\mathbf{5 0 \%}$ \\
\hline
\end{tabular}

(Source) Annual Reports and Stock Market Notices

Figure 4-Planned Rent Reversionary Uplifts for Hibernia REIT at Next Lease Event

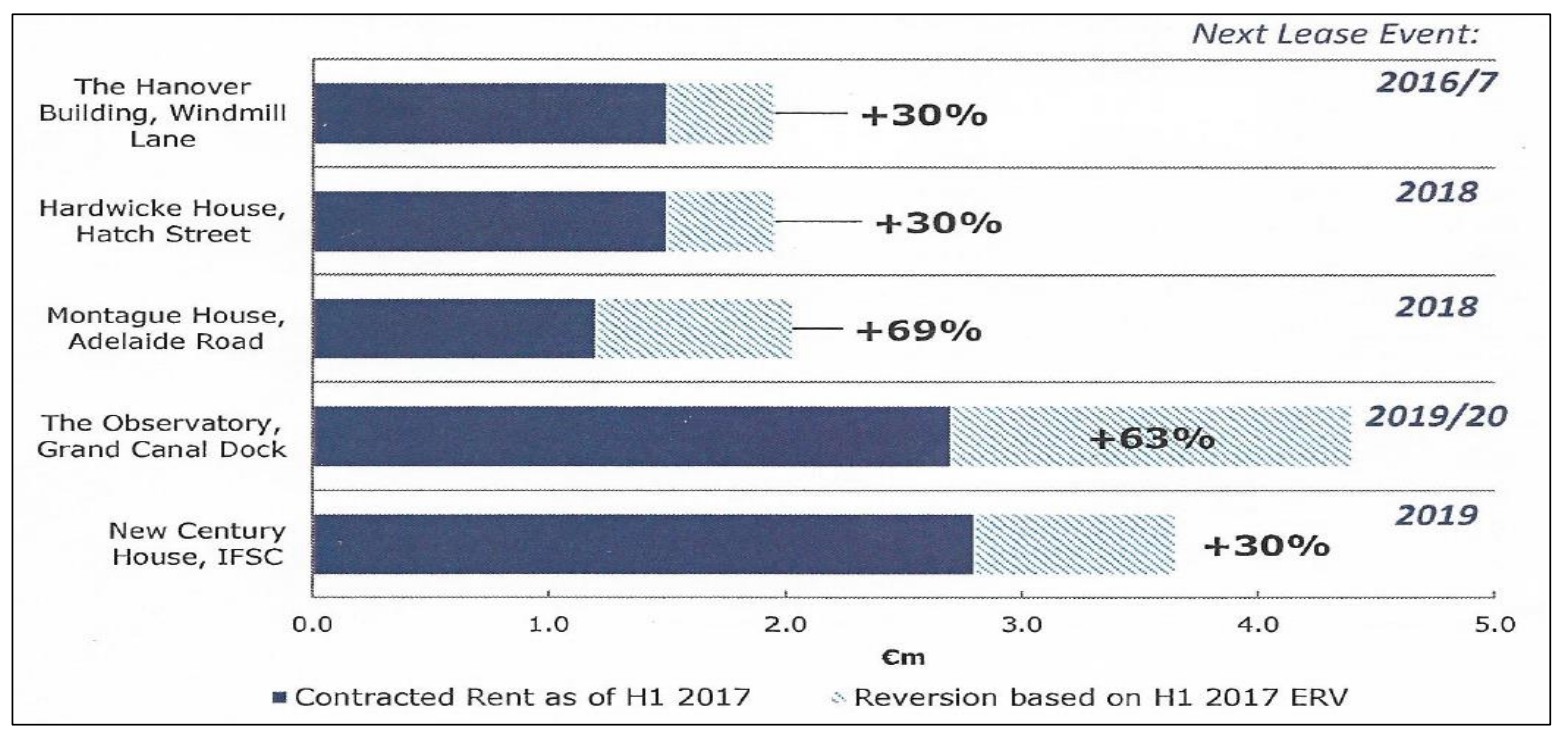

Source: (Goodbody Stockbrokers, 2016)

In the residential sector, Dublin is currently in the grip of a severe housing crisis in the provision of affordable rental accommodation. Paradoxically, having generated one of the largest percapita construction bubbles ever recorded, Irish cities are experiencing a housing supply problem caused by the collapse in construction sector and a severely restricted credit environment for development. Housing output in Dublin declined from 19,470 units in 2006 to just 2,891 in 2015, despite the need for 35,433 units to be built in the capital between 2014-2018 (SCSI, 2015). This strain is most evident in Dublin's rental market where average apartment rents have risen by a dramatic $37 \%$ (€975 - €1,335) between 2011 and 2016 (PRTB, 2016). Comparatively, average incomes have increased by just $4.7 \%(C S O, 2016)$ and tenants are on average spending more than $40 \%$ of their income on rent (National Competitiveness Council, 2016). In combination with a retrenchment in social housing provision under successive austerity budgets, enormous pressure is being placed on household finances and is leading to economic evictions and homelessness. Twenty thousand households are currently on Dublin's social housing waiting list, yet just 604 social units were under construction in 2016. Most concerning is that 5,293 people (including 2,046 children) were homeless in January 2017 (DHPCLG, 2017), or as one housing charity put it, "...a child became homeless every 5 hours in Dublin during the month of January" (Focus Ireland, 2017).

However, the REITs have exploited these conditions with remarkable effect, rewarding both investors and management with lucrative returns. Hibernia's residential rental income ballooned from $€ 0.2 \mathrm{~m}$ to $€ 5.4 \mathrm{~m}$ between 2015 and 2016, while IRES' rent roll doubled from $€ 28.2 \mathrm{~m}$ to $€ 42.3 \mathrm{~m}$ (Table 
4). IRES is the largest private landlord in the State and has aims to double its stock to 5,000 units. Average monthly rents across its portfolio jumped by $36 \%$ from $€ 1,070$ to $€ 1,459$ between 2014 and 2017 and while this growth has been driven by acquisitions, the company has also driven up individual rents through lease expiries and rent reversions. Average rents at its Beacon South Quarter development in Sandyford jumped by 28\% between 2014 and 2017, while at its Marker development in the Docklands, where an average apartment rents for $€ 2,600$, the rent roll has increased by $22 \%$. However, these averages conceal the individual increases generated by the turnover in tenants and considering that IRES' tenant turnover rate is $25 \%$, the true level of rent increases could be significantly greater. Furthermore, on the back of Dublin's strong population growth and weak levels of housing construction, the company envisages continued strong rent inflation; something it actively promotes to prospective shareholders (IRES REIT, 2017). Indeed, investor interest has soared as IRES' share price expanded by $30 \%$ over 2016/2017. The REIT's management are profiting handsomely from these conditions, as evidenced by the pay package of CEO David Ehrlich which totalled €753,000 in 2016 (Reddan, 2016). Again, such extraordinary levels of profitability and remuneration are, in many cases, underpinned by property assets that were nationalised at enormous cost to Irish taxpayers before being re-privatised to investors through State-backed sales.

\section{Redevelopment and Asset Enhancement}

Finally, while the REITs are channelling capital back to their shareholders through yieldaccretive acquisitions, selective asset disposals and rental growth, they are also seeking to unlock value and promote liquidity by 'sweating their assets' through more active portfolio management (Interviewees 2, 5, 6, 15). As discussed earlier, the REIT manager's role is to transform the spatial fixity of property into a liquid commodity that is translatable to a diverse range of geographically disconnected investors. For Haila (1988), this search for liquidity requires ever-increasingly frequent alterations in the use of urban space and the "tendency to increasing displacement of use values and the development of an abstract space....for hypothetical tenants." This enacting of liquidity must be maintained if the REIT is to continue to generate a high valuation that attracts external investors. Hence, the REIT Manager must continuously engage in 'asset enhancement initiatives' in order to remodel, refurbish and redevelop its physical properties in order to drive future yield growth and accommodate the preferences of investors and tenants which are continuously in flux (Daniels, 2015).

The REITs are increasingly turning to redevelopment to enhance investors' returns in a period when yields on Irish property are compressing. Both Green and Hibernia are engaged in a number of large development projects in core and suburban locations that will add 530,000 square feet of commercial space to their portfolios (Table 6). IRES is adding 560 apartments at two suburban residential projects, where it expects investment yields of $8 \%-9 \%$. Such asset enhancement initiatives offer justification for increasing rents, which in case of Green and Hibernia will add $€ 13.3 \mathrm{~m}$ and $€ 20 \mathrm{~m}$ to their annual rent rolls. However, asset enhancement initiatives do not solely relate to physical transformations, but also refer to both the flexibilization and standardization of buildings within the REITs' portfolios. The REIT Managers actively seek to create more generic commercial spaces, often with an emphasis on larger floor plates and open plan spaces to appeal to corporate tenants (Interviewees 2, 18). Greater emphasis is placed on developing ancillary spaces to facilitate more knowledge-intensive industries, as well as serviced spaces like gyms, concierges and cafes. However, such interventions also create a more homogenous and commodified urban environment, where buildings are produced not for any specialist purpose but simply as financial commodities designed to provide a return to investors regardless of their geographic location (Haila, 1988). 
Table 6 - Development Activity and Future Shareholder Value Creation

\begin{tabular}{|c|c|c|c|c|c|c|}
\hline & $\begin{array}{l}\text { Existing } \\
\text { Area } \\
\text { (sq ft) }\end{array}$ & $\begin{array}{l}\text { Post-Completion } \\
\text { Area } \\
\text { Sq ft) }\end{array}$ & $\begin{array}{l}\text { Purchase } \\
\text { Cost } \\
\text { (€m) }\end{array}$ & $\begin{array}{l}\text { Build } \\
\text { Cost } \\
\text { (€m) }\end{array}$ & $\begin{array}{l}\text { Est. Rental } \\
\text { Value } \\
\text { (€m) }\end{array}$ & $\begin{array}{l}\text { Est. Rental } \\
\text { Value } \\
\text { (€p sq ft) }\end{array}$ \\
\hline \multicolumn{7}{|l|}{ Green REIT } \\
\hline One Molesworth Street, Dublin 2 & 42,400 & 120,000 & $€ 24$ & $€ 38$ & $€ 4.7$ & $€ 55$ \\
\hline 4\&5 Harcourt Road, Dublin 2 & 32,400 & 64,374 & $€ 16$ & $€ 25$ & $€ 2.5$ & $€ 50$ \\
\hline 32 Molesworth Street, Dublin 2 & 12,000 & 43,292 & $€ 4$ & $€ 13$ & $€ 1.45$ & $€ 50$ \\
\hline Block H, Central Park, Dublin 18 & - & 150,000 & $€ 4$ & $€ 48$ & $€ 4.35$ & $€ 25$ \\
\hline $\begin{array}{l}\text { Horizon Logistics Park, Dublin } \\
\text { Airport }\end{array}$ & - & 44,000 & $€ 0.3$ & $€ 4.2$ & $€ 0.35$ & $€ 8$ \\
\hline \multicolumn{7}{|l|}{ Hibernia REIT } \\
\hline Cumbernauld House, Dublin 2 & 112,000 & 127,000 & $€ 51$ & $€ 27$ & $€ 7.2$ & $€ 51.4$ \\
\hline Guild House, Dublin 2 & 72,000 & 72,000 & $€ 46$ & $€ 12$ & $€ 3.9$ & $€ 50.5$ \\
\hline 1WML, Dublin 2 & - & 64,000 & $€ 4$ & $€ 26$ & $€ 3$ & $€ 47$ \\
\hline 1SJRQ, Dublin 2 & - & 116,200 & $€ 18$ & $€ 55$ & $€ 5.9$ & $€ 50.5$ \\
\hline \multicolumn{7}{|l|}{ IRES REIT } \\
\hline B2B Development, Dublin 18 & - & 68 apartments & $€ 4.3$ & $€ 22.7$ & $8.5 \%-9 \%$ yield & - \\
\hline Rockbrook Sandyford & - & 492 apartments & - & - & - & - \\
\hline
\end{tabular}

(Source) Annual Reports and Stock Market Notices

\section{Conclusions}

This article has examined the economic, political and urban implications of the resolution of finance-led real estate crashes through a focus on the establishment of a system of Real Estate Investment Trusts in Ireland. Drawing on Sokol's (2017) concept of 'financial chains,' this article understands REITs both as a mechanism of value transfer between local property markets and the global financial system and as a network of social relations that create the legislative, institutional, political and cultural conditions that enable the extraction of value and wealth from the urban built environment. Through extensive empirical analysis the article identifies the range of actors and institutions involved in the globalization of finance and real estate and the dimensions of their interactions. It also highlights the central role of the State in the 'resolution' of finance-real estate crashes, not just through the socialisation of private banking losses, but also in the development of financial instruments and policies that connect the financial and real estate markets in a more direct way. Furthermore, the paper examines the investment strategies and the asset management practices of the Irish REITs, demonstrating how they are capitalizing on the carcass of the Irish crash through spatially and sectorally specific acquisitions, through the rapid uplift in capital values and rents and through more active asset enhancement measures.

Economic crises serve as productive moments within which States can confer extraordinary powers upon themselves to shape new politico-institutional forms, policies, markets and financial instruments to further support the extraction of value from urban space in the interest of financial and real estate actors. In the Irish case, the political economy implications of the Irish State's response to the crisis are clear. Firstly, the reprivatisation of nationalised property assets and the losses experienced on those sales have imposed substantial direct costs upon dispossessed taxpayers, which ultimately have been paid for through a series of regressive austerity budgets. Secondly, this dispossession has ensured that any gains arising out of a recovering market are to be syphoned off to global investors rather than retained within the domestic economy. Thirdly, the active asset management practices of REITs and other investors have resulted in dramatically rising rents, which have fed into a new crisis in affordable housing supply and generated concerns about Ireland's broader economic competitiveness. Fourthly, rapidly rising asset values and land prices have fed into rising house prices, which are currently growing at double digit rates and pricing prospective home purchasers out of the market or leading them into greater levels of indebtedness. Indeed, this has raised new questions as to whether another boom-bust cycle has been entered into. Fifth, the scale of acquisitions by REITs and other types of investor has created a new oligopoly in the land market, 
where such actors have been accused of hoarding large portfolios of development land and bidding up land values (Qunlan, 2017).

While Irish REITs have clearly delivered exceptional returns for investors, it is worth considering the future direction of the REIT sector, particularly when the period of easy gains achieved through fire-sale acquisitions from the deleveraging banks has largely ended. Furthermore, with five million square feet of commercial office space in Dublin's development pipeline, some REIT managers are concerned about an over-supply cliff emerging in 2019 that might impact rental values. In response, the REITs have turned from an investment strategy based on acquisitions to a value-add strategy based on refurbishment and redevelopment in order to drive future growth, resulting in more intensified development pressures in the small number of locations within which the REITs have been invested. Many consider the REITs have reached their optimum size with a valuation of around $€ 1 \mathrm{bn}$ and the emergence of another large-scale generalist REIT is unlikely, but smaller, sectorally specific REITs could be a feature of the future market. A further avenue for REIT expansion is into the provision of social and affordable housing, reflective of trends witnessed elsewhere of the expansion of finance into spaces and sectors beyond traditional capital markets (Wainwright and Manville, 2017). Indeed, one REIT promoter is advancing plans to develop a pension fund-backed investment vehicle with the aim of delivering 500-1,000 subsidised housing units a year on lands provided by the state (HorganJones, 2016).

Finally, while this article has attempted to explore the political economy of real estate investment trusts and their impacts on urban space, further avenues of investigation with regard to the financialization of real estate remain. Firstly, as Poovey (2015) and Ouma (2015) have noted, there is a dearth of research regarding the operational infrastructures that support financialization in practice and further work is required to reveal the institutions, elite networks, legal frameworks, financial mathematics and econometric modelling that support financialization in practice. Secondly, as Peck (2015) contends, the literature remains underdeveloped regarding the 'meso-politics' that supports financialization in practice, meaning that knowledge is under-developed regarding the ways in which financial and development sector interests (i.e. developers, investors and financiers, REITS and other types of financial institution) seek to influence the development of economic and urban policy making that supports their own vested interests. Indeed, it remains unclear how financial and real estate actors derive their power and influence in the political sphere, the mechanisms by which they exert this influence and how they have co-opted State institutions to incorporate financial rationales, logics and methodologies within public policymaking. Thirdly, through better understanding of the mechanisms and tactics by which financial and development actors channel their influence, critical scholars might promote pragmatic contributions for resisting such pressure, for example by supporting more critical perspectives among policymakers regarding issues of path dependencies, organizational barriers and entrenched interests in the planning system. Such a program of work is urgently needed as financial and real estate interests develop ever more elusive ways of influencing processes of urban development.

\section{References}

AALBERS, M. B. 2016. The financialization of housing: A political economy approach, Oxon, UK, Routledge. ALSHEHABI, O. H. \& SUROOR, S. 2016. Unpacking “Accumulation By Dispossession", "Fictitious Commodification", and "Fictitious Capital Formation": Tracing the Dynamics of Bahrain's Land Reclamation. Antipode, n/a-n/a.

ANDRITZKY, J. R. 2014. Resolving Residential Mortgage Distress: Time to Modify? - IMF Working Paper No. 14/226. Washington DC: International Monetary Fund.

ASHTON, P. 2011. The Financial Exception and the Reconfiguration of Credit Risk in US Mortgage Markets. Environment and Planning A, 43, 1796-1812.

ASHTON, P., DOUSSARD, M. \& WEBER, R. 2014. Reconstituting the state: City powers and exposures in Chicago's infrastructure leases. Urban Studies. 
BAYLISS, K. 2014. The Financialization of Water. Review of Radical Political Economics, 46, 292-307.

BESWICK, J., ALEXANDRI, G., BYRNE, M., VIVES-MIRÓ, S., FIELDS, D., HODKINSON, S. \& JANOSCHKA, M. 2016. Speculating on London's housing future: The rise of global corporate landlords in 'post-crisis' urban landscapes. City, 20, 321-341.

BRENNAN, J. 2017. Investor mix in Irish REITs set to shift as returns slow. The Irish Times, 01/03/2017.

BRUEGGEMAN, W. B. \& FISHER, J. D. 2008. Real estate finance \& investments, New York, McGraw-Hill/Irwin.

BTG GLOBAL ADVISORY. 2015. The NPL Market - Europe 2015 [Online]. Available:

https://www.btgga.com/assets/uploads/insights/1383\%20Capital\%20Markets EMAIL.pdf [Accessed 15/03/2017.

BYRNE, M. 2015. Bad banks: the urban implications of asset management companies. Urban Research \& Practice, 8, 255-266.

BYRNE, M. 2016a. Bad banks and the urban political economy of financialization: The resolution of financialreal estate crises and the co-constitution of urban space and finance. City, 20, 685-699.

BYRNE, M. 2016b. Bouncing back: the political economy of crisis and recovery at the intersection of commercial real estate and global finance. Irish Geography, 48, 78-98.

BYRNE, M. 2016c. From Puerto Rico to Dublin's Docklands: Vulture Funds and Debt in Ireland and the Global South. Dublin: Debt and Development Coalition Ireland.

CARDIFF, K. 2016. Recap: Inside Ireland's Financial Crisis, Dublin, The Liffey Press.

CHAN, S. H., ERICKSON, J. \& WANG, K. 2003. Real estate investment trusts: Structure, performance, and investment opportunities, New York, Oxford University Press.

CHRISTOPHERS, B. 2016. Geographies of finance III Regulation and 'after-crisis' financial futures. Progress in Human Geography, 40, 138-148.

CHRISTOPHERS, B. 2017. The State and Financialization of Public Land in the United Kingdom. Antipode, 49, 6285.

CLARK, E. \& LUND, A. 2000. Globalization of a commercial property market: the case of Copenhagen. Geoforum, 31, 467-475.

COMISKEY, J. 2017. High city rents force companies to scope out suburbs in search of cheaper space. The Irish Times, 22/03/2017.

CROSBY, N. \& HENNEBERRY, J. 2015. Financialisation, the valuation of investment property and the urban built environment in the UK. Urban Studies.

CRUMP, J., NEWMAN, K., BELSKY, E. S., ASHTON, P., KAPLAN, D. H., HAMMEL, D. J. \& WYLY, E. 2008. Cities destroyed (again) for cash: Forum on the U.S. foreclosure crisis. Urban Geography, 29, 745-784.

CSO 2016. Survey on Income and Living Conditions (SILC) 2016. Dublin: Central Statistics Office.

CUSHMAN \& WAKEFIELD. 2014. European Asset Management Agencies to Offload €264bn of Non-Core Real Estate [Online]. Available: http://www.cushmanwakefield.com/en-gb/news/2014/10/europeanasset-management-agencies-to-offload-non-core-real-estate/ [Accessed 17/03/2017.

DANIELS, J. A. 2015. Securitizing Spectacle: Property Real Estate Investment Trusts and the Financialization of Retail Space in Singapore. Master of Arts, University of British Columbia.

DEPARTMENT OF FINANCE. 2012. Tax Strategy Group - International Financial Services TSG12/18 [Online]. Dublin: Department of Finance. Available: http://www.finance.gov.ie/sites/default/files/12\%2018\%20International\%20Financial\%20Services.pdf [Accessed 07/02/2017.

DERUYTTER, L. 2015. Keeping financialization under the radar? Brussels Airport, Macquarie Bank and the Belgian politics of financialized infrastructure. Master in Geography, University of Ghent.

DHPCLG. 2017. The Department of Housing, Planning, Community \& Local Government - Homelessness Report March 2017 [Online]. Department of Housing, Planning, Community \& Local Government. Available: http://www.housing.gov.ie/sites/default/files/publications/files/homeless report march 2017 0.pdf [Accessed 09/05/2017.

ELLEN, I. G., MADAR, J. \& WESELCOUCH, M. 2015. The foreclosure crisis and community development: Exploring REO dynamics in hard-hit neighborhoods. Housing Studies, 30, 535-559.

ENGELEN, E. 2015. "Don't mind the 'funding gap': what Dutch post crisis storytelling tells us about elite politics in financialized capitalism". Environment and Planning A, 47.

EY. 2016. Global perspectives: 2016 REIT report [Online]. Available: http://www.ey.com/Publication/vwLUAssets/global-perspectives-2016-reit-report-ey/\$File/ey-globalperspectives-2016-reit-report.pdf [Accessed 18/04/2017.

FERNANDEZ, R. \& AALBERS, M. B. 2016. Financialization and housing: Between globalization and Varieties of Capitalism. Competition \& Change. 
FERNANDEZ, R., HOFMAN, A. \& AALBERS, M. B. 2016. London and New York as a safe deposit box for the transnational wealth elite. Environment and Planning A, 48, 2443-2461.

FIELDS, D. 2013. From Property Abandonment to Predatory Equity: Writings on Financialization and Urban Space in New York City. PhD Dissertation, The City University of New York.

FIELDS, D. 2014. The Rise of the Corporate Landlord: The Institutionalization of the Single-Family Rental Market and Potential Impacts on Renters. New York: Right to the City Alliance, Homes for All campaign.

FLANAGAN, P. 2016. Ireland a thing of the past as 'vultures' turn their focus elsewhere. The Sunday Independent 12/06/2016.

FOCUS IRELAND. 2017. New Figures Show Record Number Now Homeless In Ireland [Online]. Available: https://www.focusireland.ie/press/new-figures-show-record-number-now-homeless-ireland/ [Accessed 09/05/2017.

FRENCH, S., LEYSHON, A. \& WAINWRIGHT, T. 2011. Financializing space, spacing financialization. Progress in Human Geography, 35, 798-819.

GERLACH, S. 2016. The Return of Ireland's Housing Bubble [Online]. Project Syndicate. Available: https://www.project-syndicate.org/commentary/ireland-housing-bubble-by-stefan-gerlach-2016-07 [Accessed 07/04/2017.

GOODBODY STOCKBROKERS 2014. Irish Property: From Stabilisation to Recovery. Dublin: Goodbody Stockbrokers.

GOODBODY STOCKBROKERS 2016. Hibernia REIT: Analyst Report November 2016. Dublin: Goodbody Stockbrokers.

GOTHAM, K. F. 2006. The Secondary Circuit of Capital Reconsidered: Globalization and the U.S. Real Estate Sector. American Journal of Sociology, 112, 231-275.

GUIRONNET, A. \& HALBERT, L. 2014. The financialization of Urban Development Projects: Concepts, processes, and implications. Document de Travail du Latts-Working Paper (14-04), 44.

HAILA, A. 1988. Land as a financial asset: the theory of urban rent as a mirror of economic transformation. Antipode, 20, 79-101.

HALBERT, L. \& ATTUYER, K. 2016. The financialisation of urban production: Conditions, mediations and transformations. Urban Studies.

HARVEY, D. 2005. A brief history of neoliberalism, Oxford, Oxford University Press.

HARVEY, D. 2011. Roepke Lecture in Economic Geography-Crises, Geographic Disruptions and the Uneven Development of Political Responses. Economic Geography, 87, 1-22.

HENDRIKSE, R. P. 2013. Entangled geographies of "Irish" finance. Eurasian Geography and Economics, 54, $182-$ 201.

HORGAN-JONES, J. 2016. Nowlan in talks with pension funds about bankrolling social housing. Sunday Business Post, 08/05/2016.

IMMERGLUCK, D. \& LAW, J. 2014a. Investing in crisis: The methods, strategies, and expectations of investors in single-family foreclosed homes in distressed neighborhoods. Housing Policy Debate, 24, 568-593.

IMMERGLUCK, D. \& LAW, J. 2014b. Speculating in crisis: The intrametropolitan geography of investing in foreclosed homes in Atlanta. Urban Geography, 35, 1-24.

IRES REIT. 2017. IRES REIT - Investor Presentation February 2017 [Online]. Available: http://investorrelations.iresreit.ie/ /media/Files/I/IRES-IR/presentations/ires-investor-presentationfeb-2017.pdf [Accessed 08/05/2017.

JANOSCHKA, M. \& ALEXANDRI, G. 2017. Who Loses and Who Wins in a Housing Crisis? Lessons from Spain and Greece for a Nuanced Understanding on Dispossession. Housing Policy Debate.

KELLY, M. 2010. The Irish Credit Bubble. In: KINSELLA, S. \& LEDDIN, A. (eds.) Understanding Ireland's Economic Crisis: Prospects for Recovery. Dublin: Blackhall Publishing.

KITSON, M., MARTIN, R. \& TYLER, P. 2011. The geographies of austerity. Cambridge Journal of Regions, Economy and Society, 4, 289-302.

KPMG. 2015. Insights on Real Estate Investment Trusts: A global overview of the REIT regimes [Online]. KPMG International Available: https://assets.kpmg.com/content/dam/kpmg/pdf/2015/03/insights-on-realestate-investment.pdf [Accessed 23/01/2017.

LANE, P. R. 2011. The Irish Crisis. Dublin: IIS, Trinity College Dublin and CEPR.

LEE, R., CLARK, G. L., POLLARD, J. \& LEYSHON, A. 2009. The remit of financial geography-before and after the crisis. Journal of Economic Geography, lbp035.

MACLARAN, A. 2014. Ready Money: Over-Development in the Offices Sector. In: MACLARAN, A. \& KELLY, S. (eds.) Neoliberal Urban Policy and the Transformation of the City: Reshaping Dublin. Basingstoke: Palgrave MacMillan. 
MALLACH, A. 2010. Meeting the Challenge of Distressed Property Investors in America's Neighbourhoods. New York: Local Initiatives Support Coalition.

MAZURCZAK, A. 2011. Development of Real Estate Investment Trust (REIT) Regimes in Europe. Journal of International Studies, 4, 115-123.

MCCABE, S. 2014. Green REIT may pay over $€ 33 \mathrm{~m}$ in fees to management outfit. Irish Independent, 23/11/2014.

MCCABE, S. 2015. Hedge fund golden boy John Paulson pulls $€ 23 \mathrm{~m}$ worth of shares from Green REIT. Irish Independent, 01/11/2015.

MCDONALD, F. \& SHERIDAN, K. 2008. The Builders: How a Small Group of Property Developers Fuelled the Building Boom and Transformed Ireland, Dublin, Penguin Ireland.

MERCILLE, J. \& MURPHY, E. 2015. Conceptualising European Privatisation Processes After the Great Recession. Antipode, n/a-n/a.

MINISTER FOR FINANCE. 2012. Budget Statement 2013 [Online]. Dublin: Oireachtas. Available: http://oireachtasdebates.oireachtas.ie/debates\%20authoring/debateswebpack.nsf/takes/dail201212 0500020?opendocument [Accessed 07/02/2017.

MURPHY, L. 2008. Globalising commercial property markets: the development and evolution of the listed property trust sector in New Zealand. In: TAMÁSY, C. \& TAYLOR, M. (eds.) Globalising Worlds: Geographical Perspectives on New Economic Configurations. London: Ashgate.

NATIONAL COMPETITIVENESS COUNCIL 2016. A Study to Examine the Affordability of Irish Housing. Dublin: National Competitiveness Council.

NOWLAN, B. 2013. Green Property REIT launch has come at right time. The Irish Times, 03/07/2013.

O'HALLORAN, B. 2015. Cerberus set to buy €6.25bn NAMA loan portfolio for $€ 800 \mathrm{~m}$. The Irish Times, 23/10/2015.

O'NEILL, F. 2013. Irish REITs: Getting ready to go. EPRA News. Brussels: European Public Real Estate Association.

Ó'RIAIN, S. 2013. The crisis of financialisation in Ireland. The Economic and Social Review, 43, 497-533.

OUMA, S. 2015. Getting in between $M$ and $M^{\prime}$ or: How farmland further debunks financialization. Dialogues in Human Geography, 5, 225-228.

PECK, J. 2015. Framing Detroit: Systemic Austerity, Structural Adjustment and the Financialization of Urban Governance [Online]. Available: https://www.youtube.com/watch?v=yRJ5fSSrwdk.

PECK, J. \& WHITESIDE, H. 2016. Financializing Detroit. Economic Geography, 1-34.

PIROLO, A. \& NEUMANN, J. 2015. European 'Cash-Box' Firms Underperform Broader Commercial Market. Wall Street Journal, 13/01/2015.

POOVEY, M. 2015. On 'the limits to financialization'. Dialogues in Human Geography, 5, 220-224.

PRTB. 2016. Private Residential Tenancies Board Rent Index - Q4 2016 [Online]. Dublin: Private Residential Tenancies Board. Available: http://www.cso.ie/px/pxeirestat/Statire/SelectVarVal/Define.asp?maintable=RIQ02\&ProductID=DB RI\&PLanguage $=0$ [Accessed 08/05/2017.

QUADRANT REAL ESTATE. 2016. Ireland Commercial Real Estate Market Update - 4th Quarter 2016 [Online]. Available: http://quadrantrea.com/quadrant/wp-content/uploads/2017/03/Q4-2016-IrelandCommerical-Real-Estate-Market-Update.pdf [Accessed 23/01/2018.

QUINLAN, R. 2016. Europe is now assessing Reit tax regime complaint. The Irish Independent, 27/10/2016.

QUNLAN, R. 2017. O'Flynn blames land prices for fuelling housing crisis. Sunday Independent, 10/12/2017.

REDDAN, F. 2016. Ireland's biggest landlord: 'I feel bad for the Irish people'. The Irish TImes, 18/11/2016.

ROBINSON, E. 2012. Foreclosures give rise to new industry. The Washington Post, 01/04/2012.

SCSI 2015. Annual Residential Property Review \& Outlook: The Report 2015. Dublin: Society of Chartered Surveyors Ireland.

SOKOL, M. 2017. Financialisation, financial chains and uneven geographical development: Towards a research agenda. Research in International Business and Finance, 39B, 678-685.

STEVENSON, S. 2013. The Global Real Estate Investment Trust Market: Development and Growth. In: SOTELO, R. \& MCGREAL, S. (eds.) Real Estate Investment Trusts in Europe. Springer.

THE ECONOMIST. 2016. The REIT Stuff [Online]. Available: http://www.economist.com/news/finance-andeconomics/21707223-explaining-boom-property-based-investment-trusts-reit-stuff [Accessed 09/03/2017.

VAN LOON, J. \& AALBERS, M. B. 2017. How real estate became 'just another asset class': the financialization of the investment strategies of Dutch institutional investors. European Planning Studies, 25, 221-240. 
WAINWRIGHT, T. \& MANVILLE, G. 2017. Financialization and the third sector: Innovation in social housing bond markets. Environment and Planning A, 49, 819-838.

WALDRON, R. \& REDMOND, D. 2016. Stress in Suburbia: Counting the Costs of Ireland's Property Crash and Mortgage Arrears Crisis. Tijdschrift voor economische en sociale geografie, 107, 484-501.

WALDRON, R. \& REDMOND, D. 2017. "We're just existing, not living!" Mortgage stress and the concealed costs of coping with crisis. Housing Studies, 32, 584-612.

WHITESIDE, H. 2012. Crises of Capital and the Logic of Dis Possession and Repossession. Studies in Political Economy, 89, 59-78.

WIJBURG, G. \& AALBERS, M. B. 2017. The alternative financialization of the German housing market. Housing Studies, 1-22.

WILLIAMS, B. 2014. Bailing Out the Banks: The Role of the National Asset Management Agency. In: MACLARAN, A. \& KELLY, S. (eds.) Neoliberal Urban Policy and the Transformation of the City: Reshaping Dublin. Basingstoke: Palgrave Macmillan.

WILLIAMS, B. \& NEDOVIC-BUDIC, Z. 2016. The real estate bubble in Ireland. Policy context and responses. Urban Research \& Practice, 9, 204-218. 